\title{
Retraction Note to: Comments on 'Strategic Manoeuvring with the Intention of the Legislator in the Justification of Judicial Decisions'
}

\section{Peter J. Schulz ${ }^{1}$}

\section{Retraction Note to: Argumentation (2008) 22:355-357 DOI 10.1007/s10503-008-9092-0}

This article has been retracted by the Editor-in-Chief, because it does not appropriately acknowledge publication Adrian Vermeule, Judging Under Uncertainty: An Institutional Theory of Legal Interpretation (Cambridge, MA, Harvard University Press, 2006), as the primary source of the comments made in the article.

The online version of the original article can be found under doi:10.1007/s10503-008-9092-0.

Peter J. Schulz

peter.schulz@lu.unisi.ch

1 Institute of Communication \& Health, University of Lugano $(\mathrm{CH})$, Lugano, Switzerland 